\title{
Mobile Food Ordering Application using Android OS Platform
}

\author{
Michael Yosep Ricky \\ Computer Science Department, School of Computer Science, Bina Nusantara University, Jakarta, Indonesia
}

\begin{abstract}
The purpose of this research is making an ordering food application based on Android with New Order, Order History, Restaurant Profile, Order Status, Tracking Order, and Setting Profile features. The research method used in this research is water model of System Development Life Cycle (SDLC) method with following phases: requirement definition, analyzing and determining the features needed in developing application and making the detail definition of each features, system and software design, designing the flow of developing application by using storyboard design, user experience design, Unified Modeling Language (UML) design, and database structure design, implementation an unit testing, making database and translating the result of designs to programming language code then doing unit testing, integration and System testing, integrating unit program to one unit system then doing system testing, operation and maintenance, operating the result of system testing and if any changes and reparations needed then the previous phases could be back. The result of this research is an ordering food application based on Android for customer and courier user, and a website for restaurant and admin user. The conclusion of this research is to help customer in making order easily, to give detail information needed by customer, to help restaurant in receiving order, and to help courier while doing delivery.
\end{abstract}

\section{Introduction}

The population in Indonesia especially in Jakarta is growing from year to year. It gives opportunities to the restaurant industries to develop their business. According to the population census in 2010 , Jakarta population had recorded by more than 9,6 million people with 1 to 2 percent(s) growing each year.

Table 1. Jakarta Population Growth in 2006-2010 [3]

\begin{tabular}{|c|c|c|}
\hline Year & Population & Population Growth (\%) \\
\hline 2006 & 8.949 .716 & - \\
\hline 2007 & 9.064 .591 & 1 \\
\hline 2008 & 9.146 .181 & 1 \\
\hline 2009 & 9.223 .000 & 1 \\
\hline 2010 & 9.607 .787 & 2 \\
\hline
\end{tabular}

Based on the data in 2010, Java and Bali island had given the number of restaurant contribution in Indonesia by more than 73,6 percents. Jakarta had the greatest contribution with 26,1 percents of the total restaurants in Indonesia.
Table 2. Restaurant Distribution in Java and Bali Island in 2010 [12]

\begin{tabular}{|l|c|}
\hline \multicolumn{1}{|c|}{ Area } & $\begin{array}{c}\text { Restaurant } \\
\text { Contribution (\%) }\end{array}$ \\
\hline Jakarta & 26,1 \\
\hline Jawa Barat & 12,4 \\
\hline Bali & 12,3 \\
\hline Jawa Timur & 10,1 \\
\hline Jawa Tengah & 8,6 \\
\hline Yogyakarta & 3,7 \\
\hline
\end{tabular}

The growing number of restaurants makes restaurant development more competitive. Therefore, all restaurants keep improving their quality of service; one of the services is delivery order. Delivery order service offered by a number of restaurants is by making order through mobile phone. By following the technology development, some popular restaurants offered website as a choice for making orders in online mode [12].

Order with using online website such as www.foodpanda.co.id and www.klik-eat.com requires its customer to do registration first by filling too many profile information. Moreover, not all ordering food websites provide pictures and menus descriptions for its customer. 
Making orders through phone calling, short messages, or even website does not give order status information in real time to its customer. Moreover, customers can not see their order history which has been done before. Nowadays, mobile phone is not used for calling or sms only, many mobile phones also provide application that support people daily activities [3].

According to Ericsson Lab research from early 2011 until the end of 2011, smart phone users especially in Indonesia are increasing significantly [14]. Based on the data in the end of 2011, the smart phone operating system that is widely used is dominated by some leading platforms such as Android, iOS, and Blackberry. Android is one of the most rapidly increased platforms. In Indonesia, the International Data Corporation (IDC) recorded that the smart phone market share with Android platform raised from the third quarter of 2011 until the end of the fourth quarter of 2011 by 28 percents [19].

\begin{tabular}{|c|c|c|c|}
\hline \multicolumn{4}{|c|}{$\begin{array}{l}\text { Top Smartphone Platforms } \\
3 \text { Month Avg. Ending Mar. } 2012 \text { vs. } 3 \text { Month Avg. Ending Dec. } 2011 \\
\text { Total U.S. Smartphone Subscribers Ages 13+ } \\
\text { Source: com Score MobiLens }\end{array}$} \\
\hline & \multicolumn{3}{|c|}{ Share (\%) of Smartphone Subscribers } \\
\hline & Dec-11 & Mar-12 & Point Change \\
\hline Total Smartphone Subscribers & $100.0 \%$ & $100.0 \%$ & N/A \\
\hline Google & $47.3 \%$ & $51.0 \%$ & 3.7 \\
\hline Apple & $29.6 \%$ & $30.7 \%$ & 1.1 \\
\hline RIM & $16.0 \%$ & $12.3 \%$ & -3.7 \\
\hline Microsoft & $4.7 \%$ & $3.9 \%$ & -0.8 \\
\hline Symbian & $1.4 \%$ & $1.4 \%$ & 0.0 \\
\hline
\end{tabular}

Fig. 1. The Research Result of Mobile Phone Users in December 2011 - March 2012 Period

From all backgrounds above, developers decided to create an ordering food application with Android OS platform named "Pick The Food". Pick the Food application gives restaurant list information with menus; provides some features such as new order, order history, and order status with Global Positioning System (GPS) service.

\section{Research Method}

Pick The Food application is created by using waterfall model of System Development Life Cycle (SDLC). The SDLC phases are:

\section{Requirements definition}

Analyzes based on similar application and determines the necessary features in the application, as well as do the details about the features that will be created with function of each features.

Features that are needed in application for customer are as follows:

\section{a. New Order}

New Order is the main feature of the customer side application that will be used to make orders. There are two ways to make an orders, the first one is using Make a new order feature to make an order by choosing restaurant and menus provided freely, and the second one is using My Favorites feature to make an order by choosing one of the top three favorites restaurant.

\section{b. Order History}

Order History is the feature that will be used to show customer's order history. This feature is divided to three parts, which are Last order, Last 3 orders, and Last 7 orders that have been made by customer.

\section{c. Restaurant Profile}

Restaurant profile is the features that will be used to show restaurant profile. Customer can make a call directly to the restaurant through this feature.

\section{d. Order Status}

Order status is the feature that will used to show order status consist of "order received" means that order has been received by restaurant, "order confirmed" means that order has been confirmed by restaurant, "cooking" means that order has being prepare by restaurant, "delivering order" means that order has being delivery, and "done" means that order has been done. Customer can also show the delivery map while the status is on "delivering order".

\section{e. Profile Setting}

Profile Setting is the feature that will be used to show and to change customer profile, consist of name, address, email, and phone number.

Features that are needed in website for restaurant are as follows:

\section{a. Profile}

Profile is the feature that will be used to show restaurant profile. Restaurant can also modify its data including change password, edit profile, and change restaurant logo.

\section{b. Order}

Order is the feature that will be used to show incoming order. Restaurant can also update order status, assign courier, and show order history through this feature.

c. Menu

Menu is the feature that will be used to show the list of menus. There are two types of menu which are "food" and "beverage". Restaurant can also modify its menu including change the availability status of each menu through this feature.

\section{d. Courier}

Courier is the feature that will be used to show the courier list of restaurant. Restaurant can also modify its courier data including change availability status and 
declare delivery starting to run by courier through this feature.

Features that are needed in website for admin are as follows:

\section{a. Resto}

Resto is the feature that will be used to show restaurant list. Admin can insert new restaurant and modify restaurant data including change restaurant active or inactive status through this feature.

\section{b. Order}

Order is the feature that will be used to show order list which has been done by each restaurant.

\section{c. Menu}

Menu is the feature that will be used to show menu list of each restaurant. Admin can also modify each menu through this feature.

\section{d. Courier}

Courier is the feature that will be used to show courier list of each restaurant. Admin can also modify each courier data through this feature.

\section{e. Customer}

Customer is the feature that will be used to show customer list in this application. Admin can also edit customer profile through this feature.

Features that are needed in application for courier are as follows:

\section{a. Delivery List}

Delivery list is the feature that will be used to show delivery list progressing by courier. Courier can mark the delivery which has been done through this feature.

\section{b. Tracking Order}

Tracking order is the feature that will be used to show delivery map, consist of courier position and customer address.

\section{System and software design}

Make the application design workflow for customer side, restaurant side, courier side, and admin side using the storyboard design; the user experience design; the Unified Modeling Language (UML) design consist of use case, class diagram, sequence diagram, and activity diagram; and database structure design.

\section{a. Storyboard design}

The storyboard design is designing the user interface including each interface description.

b. User experience design
The user experience design is designing the totality of end user perception when interacting with the application.

c. UML design

The UML design consists of use case to define the system function from each actor perspective then completed by explanation in use case narrative, activity diagram to draw the process of each actor in diagram, class diagram to draw object or class of system with its relationship, and sequence diagram to draw the message interaction with its objects base on its order of time.

\section{d.Database structure design}

Database structure design is made by the result of class diagram. It draws the classes that need to be saved in database and its relationship.

\section{Implementation and unit testing}

This is the developing application phase; it includes making database and translating the design result done in the previous phases to programming language codes. After that, a program unit testing will be done.

The application development divided to two phases, which are:

\section{a. Database making}

Database is made based on the design. It used MySQL database management system which will be related between the applications developed in Android OS and the website developed in using Java Server Page (JSP).

\section{b. Application and website development}

This phase is translating the result of design into Java Programming for customer and courier side application, and Java Server Page for restaurant side and admin side websites.

After doing these two phases, a program unit testing will be done.

\section{Integration and system testing}

After doing program unit testing in the previous phase, all applications and websites will be integrated into one whole system. After that, a system testing will be done. The applications and websites will be integrated using one database.

\section{Operation and maintenance}

After doing integration into one whole system, if there is any changes or reparations needed then the previous phases can be back.

\section{Results}

\subsection{Application Screenshots}


Fig. 3. Several screenshots of Pick the Food application for courier

Below are several screenshots of Pick the Food application for customer

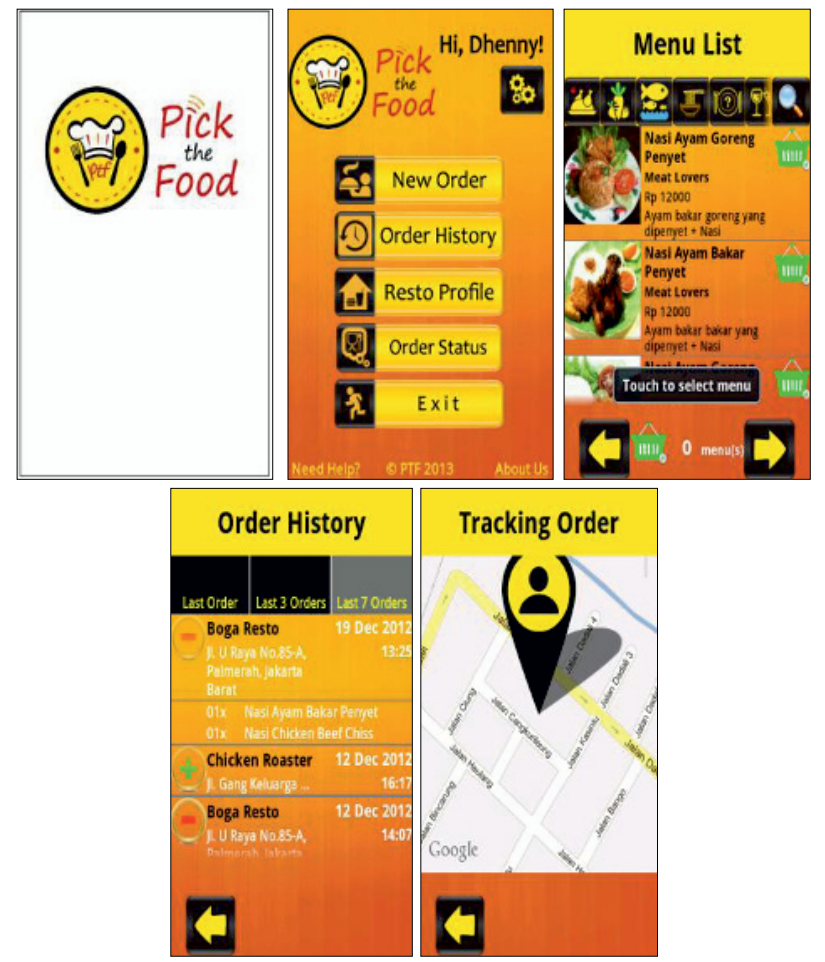

Fig. 2. Several screenshots of Pick the Food application for customer

Below are several screenshots of Pick the Food application for courier
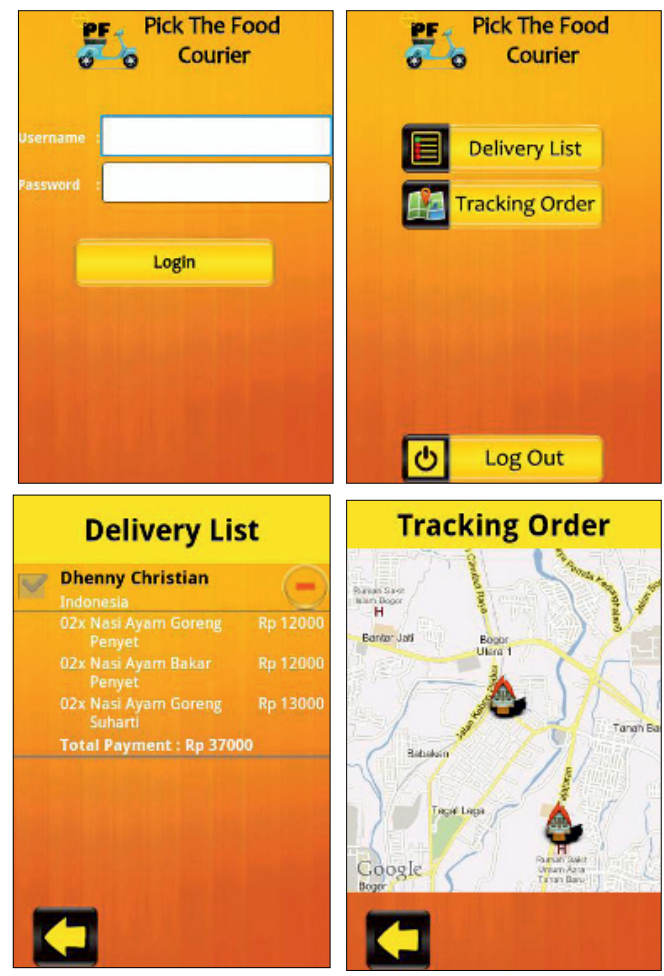

Below are several screenshots of Pick the Food application for restaurant

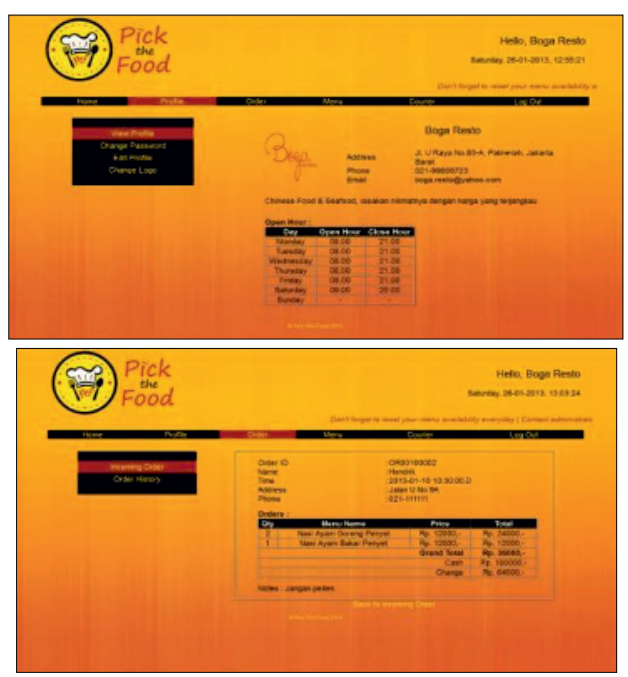

Fig. 4. Several screenshots of Pick the Food application for restaurant

Below are several screenshots of Pick the Food application for admin

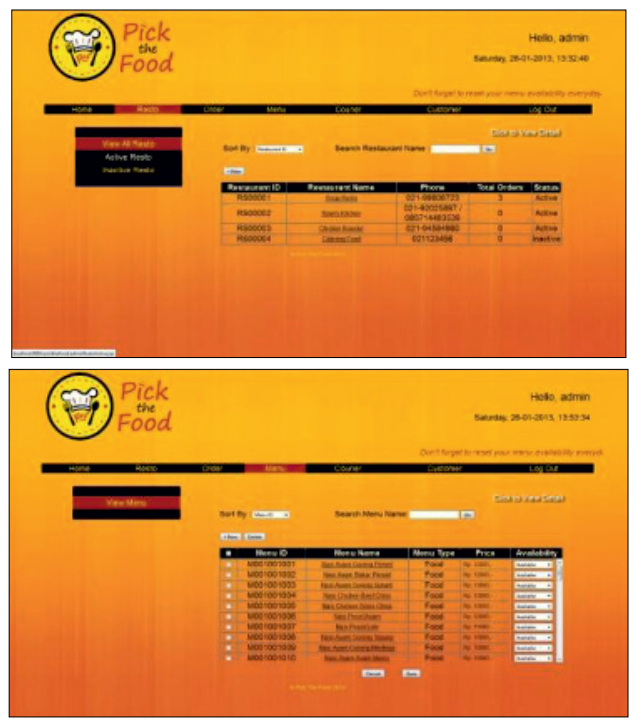

Fig. 5. Several screenshots of Pick the Food application for admin

\subsection{Application Evaluation Based on Similar Application Comparison}


Table 3. Similar application comparison

\begin{tabular}{|l|c|c|}
\hline \multicolumn{1}{|c|}{ Feature } & $\begin{array}{c}\text { Food Delivery } \\
\text { Depok on Call }\end{array}$ & Pick The Food \\
\hline $\begin{array}{l}\text { Based on Android } \\
\text { OS }\end{array}$ & $\checkmark$ & $\checkmark$ \\
\hline $\begin{array}{l}\text { Order by Phone } \\
\text { Calling }\end{array}$ & $\checkmark$ & $\checkmark$ \\
\hline $\begin{array}{l}\text { Order by } \\
\text { Application }\end{array}$ & - & $\checkmark$ \\
\hline GPS Tracking & - & $\checkmark$ \\
\hline Category Menu & - & $\checkmark$ \\
\hline Multi Restaurant & $\checkmark$ & $\checkmark$ \\
\hline Order History & - & $\checkmark$ \\
\hline My Favorite & - & $\checkmark$ \\
\hline $\begin{array}{l}\text { Order Status (real } \\
\text { time) }\end{array}$ & - & $\checkmark$ \\
\hline
\end{tabular}

The similar application compared to Pick the Food application is Food Delivery Depok on Call application [21]. By comparing to Pick the Food application, it can only be run in offline mode, it can only be used to show menu, and the order can only be made by phone calling, while Pick The Food application show user the menu pictures and description, moreover the order is made through application in online mode.

Food Delivery Depok on Call application does not have several features provided in Pick the Food application, such as "Order History" to show the order which has been made by user, "My Favorite" to show user's favorite menu, and "Order Status" to show order status in real time to user.

\subsection{Application Evaluation Based on Eight Golden Rules}

Below are the user interface evaluation based on eight golden rules [23]:

\section{Consistency}

Pick The Food keeps its consistency by using the same font type, color, layout, menu, and menu icon in each pages. It applies to website application and mobile application.

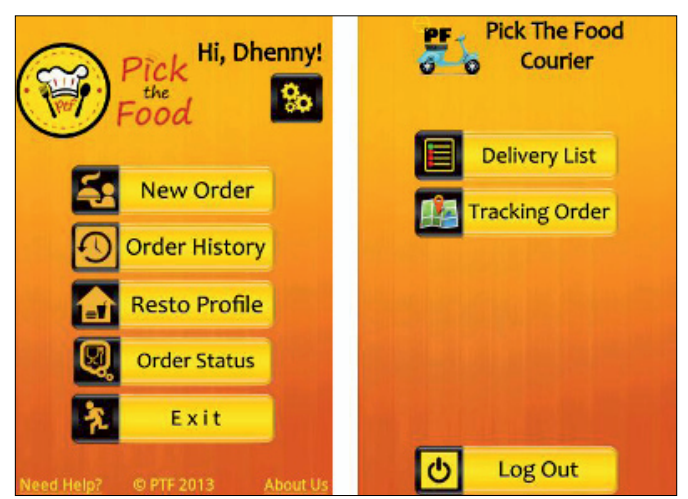

Fig. 6. Consistency of Pick The Food

\section{Provide Universal Usability}

Pick The Food interface is made user friendly so it eases user to use the application. It can be seen in the Back button provided in both customer side and courier side application which is using the universal icon and similar to user.

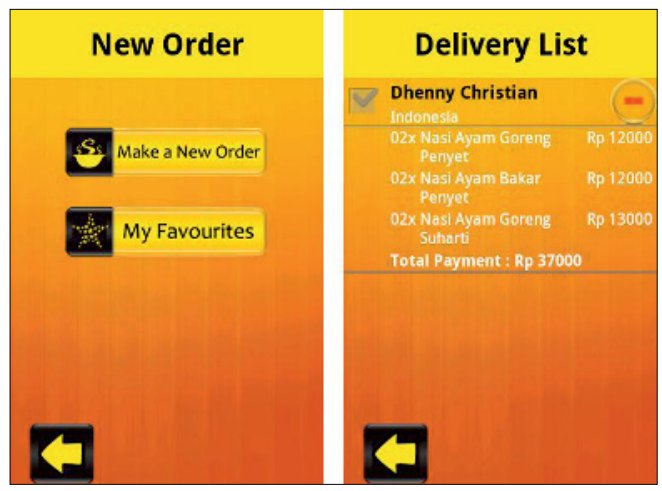

Fig. 7. Universal Usability of Pick The Food

3. Provide Information Feedback

Pick The Food gives appropriate feedbacks to users, so if there is any error happened, then there will be a feedback dialog toward users.
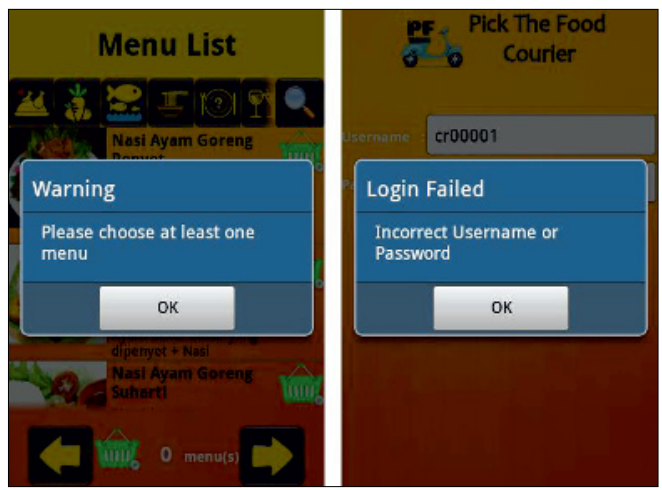

Fig. 8 Provide Informative Feedback

\section{Design Final Dialog}

Pick The Food application is made to ease user in understanding their action while using it. For example, in the application for customer, there is a final dialog confirmation in setting interface while users try to edit their profile. 


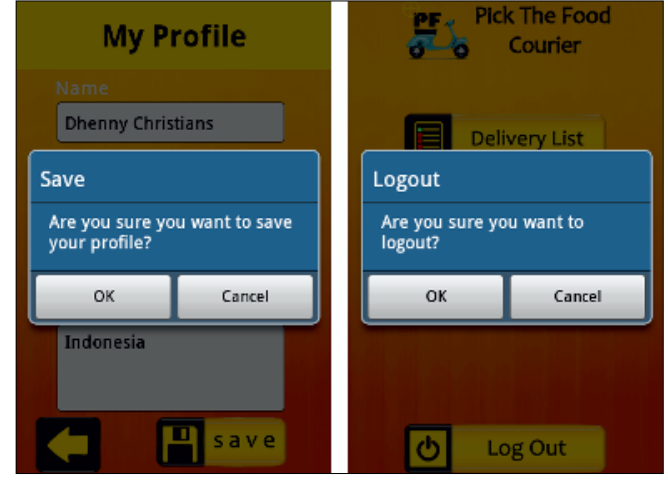

Fig. 9. Confirmation Final Dialog

\section{Simple Error Handling}

Pick The Food application is designed to avoid users doing fatal errors. For example in the application for customer side, there is a message appeared in the beginning and if users do not choose any menu and press the next button directly, then there will be an error handling dialog appeared.

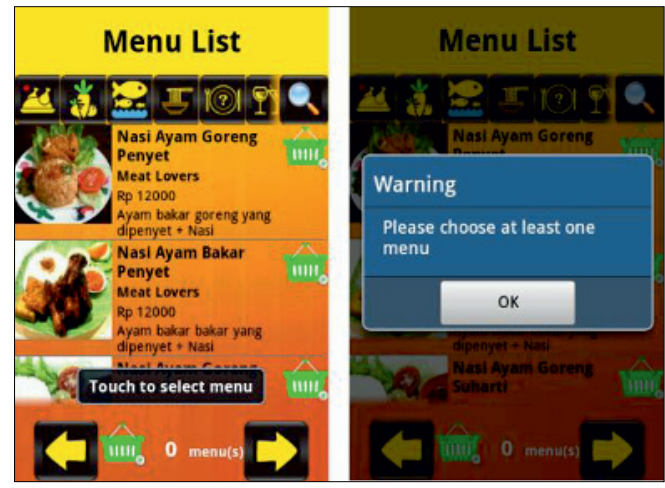

Fig. 10. Simple Error Handling

\section{Reversal Action Allowance}

Pick The Food application has integrated the simple reversal action. For example, there is a Back button in almost all interfaces for both customer side and courier side application.

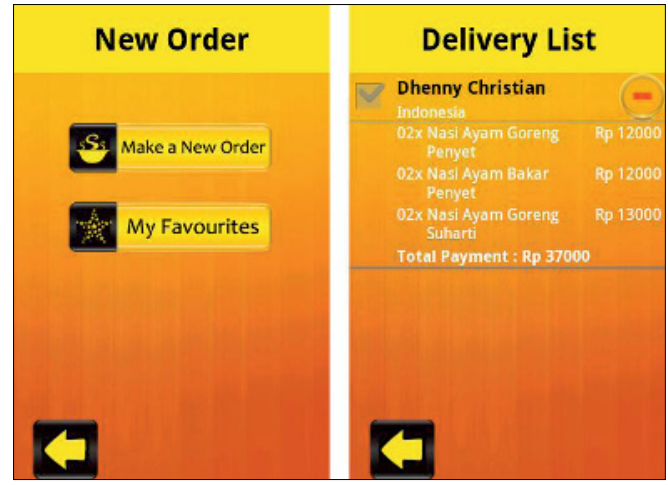

Fig. 11. Reversal Action Allowance

7. Internal Locus of Control

In Pick The Food application, users become the system controller and system will response user's action. For example in the customer side application, there is a feature to let users change their own profile.

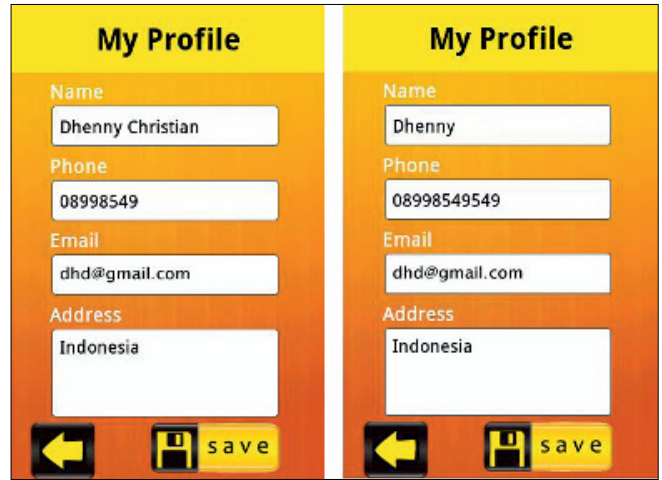

Fig. 12. Internal Locus of Control

8. Reduce the Information Capacity for Short-Term Memory

Pick The Food application has integrated the reduction of information capacity for short-term memory. For example, the menu icons used relevant icons with the menu such as exit button used the exit door icon.

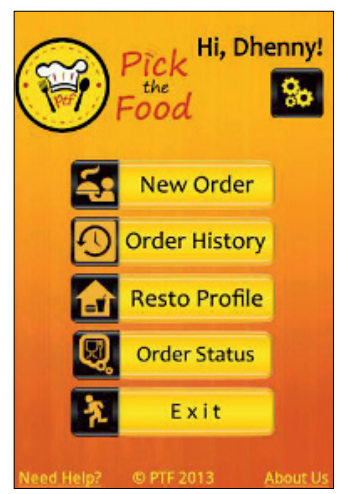

Fig. 13. Relevant Icon in each menu

\section{Conclusions and Suggestions}

\subsection{Conclusions}

Based on the result of this research, it can be concluded:

1. Pick The Food application can help customer in making order easily, 
2. Pick The Food application gives information needed in making order to customer.

3. Pick The Food website application made for restaurant can help restaurant in receiving orders and modifying its data

4. Pick The Food website application made for admin can help admin in controlling all Pick The Food system.

5. Pick The Food application made for courier can help courier while doing delivery.

\subsection{Suggestions}

Below are some suggestions addressed to the next Pick The Food application development:

1. For the next development, this application can be developed to another platform such as Blackberry and iOS, therefore other customers who are using Blackberry operating system and iOS can also use this application and the target user segmentation will also be wider.

2. For the next development, this application can be developed by adding other payment method such as klikBCA, Visa, MasterCard, etc to facilitate customer in payment process.

3. For the next development, this application can be integrated with social media such as Facebook, Twitter, etc to facilitate customer in getting Pick The Food application information.

\section{References}

1. Abidin, H.Z., Andreas H., Gamal M, Darmawan D. Land Subsidence Characteristics of Bandung Basin (Indonesia) between 2000 and 2005 as Estimated from GPS Surveys. Retrieved on 09-11-2012 from http://geodesy.gd.itb.ac.id/hzabidin/wpcontent/uploads/2007/02/fig-2006-bandungpaper.pdf (2006)

2. Anonim1. Profile Daerah DKI Jakarta. Retrieved on 09-10-2012 from http://regionalinvestment.bkpm.go.id/newsipid/id/de mografipendudukjkel.php?ia=31\&is=37 (2012)

3. Anonim2. Mengetahui Perkembangan Handphone di Indonesia dari Tahun ke Tahun. Retrieved on 09-112012 from http://portal.paseban.com/news/7381/perkembanganhandphone-di-indonesia (2012)

4. Anonim3. (n.d). SQLite. Retrieved on 01-15-2013 from www.sqlite.org. (2013)

5. Anonim4. (n.d). Android, the world's most popular mobile platform. Retrieved on 01-15-2013 from http://developer.android.com/about/index.html (2013)

6. Anonim5. (n.d). Analytics for a Digital World. Retrieved on 09-11-2012 from http://www.comscore.com (2012)

7. Anonim6. (n.d). Kamus Bahasa Indonesia Online. Retrieved on 01-27-2013 from http://kamusbahasaindonesia.org/

8. Anonim7. (n,d). What is Java technology and why do I need it?. Retrieved on 01-28-2013 from http://www.java.com

9. Castro, Elizabeth. (2007). HTML, XHTML, And CSS : Visual Quick Guide. (6th Edition). New York: Peachpit Press.

10. Chaudhuri, Anil B. (2005). The Art of Programming Through Flowcharts and Algorithms. (1st Edition). New Delhi : Firewall Media.

11. Connolly, Thomas M., Begg, Carolyn E. (2005). Database Systems: A Practical Approach to Design, Implementation and Management. (4th edition). London: Pearson Education.

12. Firmansyah, Hilman. (2010). Sebarah Wilayah Usaha : Peluang Usaha Rumah Makan / Restoran. Retrieved on 09-10-2012 from http://binaukm.com/2010/05/sebaran-wilayah-usahapeluang-usaha-rumah-makan-restoran/.

13. Garrett, Jesse J. (2010). The Elements of User Experience: User-Centered Design for the Web and Beyond. (2nd Edition). Berkeley : New Riders

14. Intana, Lila. (2012). Tahun ini Pengguna Smartphone Naik 3 Kali Lipat. Retrieved on 09-11-2012 from http://swa.co.id/technology/tahun-ini-penggunasmartphone-naik-3-kali-lipat.

15. Iwarere, H.T. \& Fakokunde, T.O. (2012). Consumers Perception of Product and Service Quality and Price in the Nigerian Fast Food Industry: A Case of Selected Outlets in Ekiti State, Nigeria. European Journal of Social Sciences, 19(2), 198-207.

16. Kadir, Abdul. (2004). Dasar Pemograman Web Dinamis dengan JSP (Java Server Pages). Yogyakarta: Andi.

17. Kuniavsky, Mike. (2010). Smart Things: Ubiquitous Computing User Experience Design. (1st Edition). Burlington : Morgan Kaufmann.

18. Moussal, M.H.B.E., Eliasl, A.N.E., and Soliman S. (2012). Evaluating Food Quality Attributes in Table and Delivery Services in Fast Food Operations. Academic Gida, 10(1), 6-11

19. Nugraha, Firman (2012). Data Seputar Industri Mobile di Indonesia dan Dunia. Retrieved on 09-1212 from http://www.teknojurnal.com/2012/05/29/dataseputar-industri-mobile-di-indonesia-dan-dunia/.

20. Prihatna, Henky. (2005). Kiat Praktis Menjadi Web Master Professional. Jakarta : PT.Elexmedia komputindo.

21. Sari, K.S. (2012). Pembuatan Aplikasi Food Delivery Depok on Call Berbasis Android. Retrieved on 09-14-12 from http://library.gunadarma.ac.id/repository/view/37168 3/pembuatan-aplikasi-food-delivery-depok-on-callberbasis-android.html/. 
22. Satzinger, John W., Jackson, Robert B., dan Burd, Stephen D. (2010). Systems Analysis and Design in a Changing World. (5th edition). Boston: Cengage Learning.

23. Shneiderman B, Plaisant C, Cohen M, dan Jacobs S. (2010). Designing the User Interface: Strategies for Effective Human-Computer Interaction. (5th edition). New York : Addison-Wesley.

24. Solichin,Achmad.(2010). MySQL 5 : From Pemula Hingga Mahir. Jakarta

25. Somerville, Ian. (2011). Software Engineering. (9th edition). New York: Addison-Wesley.

26. Stallings,Willam.(2011). Operating Systems: Internals and Design Principles. (7th edition). New Jersey : Prentice Hall.

27. Stark, J. (2012). The 10 Principles of Mobile Interface Design. Retrieved on 30-8-2012 from http://www.netmagazine.com/features/10-principlesmobile-interface-design

28. Supriyanto, Aji. (2008). Pengantar Teknologi Informasi. Jakarta: Salemba Infotex.

29. Syed. (2012). The History of Android: From Cupcakes to Jelly Beans. Retrieved on 10-11-2012 from http://droidlessons.com/the-history-of-androidfrom-cupcakes-to-jelly-beans/

30. Tanenbaum, Andrew S. (2007). Modern Operating Systems. (3rd edition). New Jersey : Prentice Hall.

31. Vaughan, Tay. (2011). Multimedia Making It Work. (8th edition). New York : Mc Graw Hill.

32. Whitten, Jeffrey L. and Lonnie D. Bentley. (2007). System Analysis and Design Methods. (6th edition). New York: McGraw-Hill Irwin.

33. Yadav, Manish. (2011). History of Android. Retrieved on 10-11-2012 from http://www.tech2crack.com/history-android/ 